\title{
Nutrition and puberty in the female
}

By R. N. Kirkwood ${ }^{1}$, D. C. Cumming ${ }^{2}$ and F. X. Aherne ${ }^{1 *}$, Departments of 'Animal Science and 'Obstetrics and Gynaecology and Medicine, University of Alberta, Edmonton, Alberta $T 6 \mathrm{G}_{2} P_{5}$, Canada

Puberty in female mammals is commonly defined as the time at which reproduction first becomes possible, whereas sexual maturity is achieved when an animal expresses its full reproductive potential (Asdell, 1946). Puberty will not occur until an animal has achieved a size and level of development commensurate with a high likelihood of successful reproduction. Therefore, it is not unreasonable to suggest that physical growth and physiological development are intimately related and that an effect on physical growth will influence physiological development.

Many authors have suggested that various diverse factors known to influence pubertal development in humans are caused by alterations in the nutritional status of the prepubertal child and adolescent. However, body-weight at puberty for any particular species, expressed in either absolute terms or as a percentage of mature body-weight, is not constant. Pubertal weights ranging from 50 to $70 \%$ of adult body-weight have been reported for ewes (Dyrmundsson, 1981). Studies of swine (Dickerson et al. 1964) and sheep (Foster \& Ostler, 1985) indicate that a certain minimum weight must be achieved before puberty occurs.

Experimental evidence of nutritional effects on pubertal development in animals is usually obtained by changing energy intake, protein intake or both. However, ethical considerations usually preclude severe controlled manipulation of human dietary intake. Therefore, findings from human studies tend to be observational and indirect, and are often obtained from situations in which differences between subjects are much more complicated than is possible with a simple nutritional experiment on animals. However, studies of changes in weight and body composition throughout puberty in humans and in association with undernutrition, anorexia nervosa, obesity, dieting and exercise have provided evidence to suggest that alterations in nutritional status in women may modify physical maturation, the age of menarche (onset of cyclic bleeding in the human female, which is not always accompanied by ovulation; a period of 'adolescent sterility' of $\mathrm{I}-3$ years duration usually follows menarche) and maintenance of regular menstrual cycles.

In this review, evidence for nutritional effects on reproductive development will be drawn initially from studies of laboratory and domestic livestock (cattle, sheep and pigs). Studies of nutritional effects on human reproductive development will

-For reprints. 
be dealt with separately. In the final section, studies of endocrine consequences of dietary manipulations are reviewed and their relations to onset of puberty are discussed.

\section{Puberty in laboratory and domestic animals}

Plane of nutrition. Studies with rats demonstrated that a dietary restriction that resulted in a $50 \%$ reduction in weaning weights of rats led to an increased age at both vaginal patency and first oestrus. Furthermore, although the undernourished groups were lighter at vaginal patency, weights at first oestrus were very similar to those of control animals (Kennedy, 1957; Widdowson \& McCance, 1960; Kennedy \& Mitra, 1963), indicating a weight dependency for the onset of puberty. In contrast, Bakke et al. (1975) and Ronnekleiv et al. (1978) reported that preweaning undernutrition led to differences in weight, but not age, at vaginal patency and first oestrus. This contradiction may be explained by differences in the severity of undernutrition. Despite using almost identical experimental protocols, weaning weights in the early studies (e.g. Kennedy, 1957) were $50 \%$ lower in the undernourished group compared with controls, while in the later studies (e.g. Bakke et al. 1975) a weight difference of only $22-35 \%$ was achieved. While Arije \& Wiltbank (197I) reported that heavier weaning weights were associated with carlier puberty in heifers, studies with pigs noted no effect of weaning weight on age or weight at puberty. However, piglet-weaning-weight differences between undernourished and control groups were in the order of only $30 \%$ (Nelson \& Robison, 1976). Results suggest that preweaning undernutrition can influence subsequent reproductive development, but the effects may only be evident when preweaning growth has been severely retarded and the animal fails to compensate in the postweaning period.

With respect to postweaning nutrition, restricting feed intake to $50 \%$ of ad lib. intake will delay the onset of puberty in female pigs (gilts) (Table $\mathrm{I}$ ), whereas a less severe restriction (60-80\% of ad lib. intake) leads to variable results (Table 2$)$. A severe feed restriction will delay puberty because all somatic growth will be slowed

Table $\mathrm{I}$. Influence of severe feed restriction ( $50 \%$ ad lib. intake) on age at puberty in gilts (from Kirkwood, 1985)

$\begin{array}{lcc}\text { Energy intake (MJ/d) ... } & \text { Low ( I } 7.9) & \text { High }(36 \cdot 3) \\ \text { Age at puberty }(\mathrm{d}) & 214 \cdot 7 & 188 \cdot 3 \\ \text { Wt at puberty }(\mathrm{kg}) & 60.7 & 83.3\end{array}$

Table 2. Influence of feed or energy restriction during rearing on age at puberty in gilts (adapted from den Hartog $\mathscr{E}^{2}$ van Kempen, 1980)

$\begin{array}{ccc}\begin{array}{c}\text { Increase } \\ \text { in age }\end{array} & \begin{array}{c}\text { No } \\ \text { effect }\end{array} & \begin{array}{c}\text { Decrease } \\ \text { in age }\end{array}\end{array}$


and, as the reproductive system has a low priority for feed energy and protein (Gunther, cited in den Hartog \& van Kempen, 1980), puberty must be delayed. The level of development achieved before feed restriction is important. Etienne et al. ( 1983 ) reported that a moderate feed restriction ( $77 \%$ of $a d$ lib. intake) from 28 to $60 \mathrm{~kg}$ live weight delayed the onset of puberty in gilts, but restriction between $60 \mathrm{~kg}$ body-weight and puberty had no effect. There may be a critical period of development in which even a moderate feed restriction will slow reproductive development, and beyond which only a very severe feed restriction (e.g. $50 \%$ ) will delay puberty (Aherne \& Kirkwood, 1985). Experiments in which total feed intake has been restricted do not allow a distinction between possible separate effects of energy and protein deficiency.

Energy intake. Kennedy \& Mitra (1963) suggested that positive energy balance is necessary for the onset of puberty in female rats. This has been confirmed by Frisch et al. (1975) who reported that age at first oestrus in rats was correlated with food intake per unit body-weight. In heifers, increasing rumen propionate: acetate ratio (by increasing the concentrate component of isoenergetic diets, or by feeding monensin) decreases the age at puberty with no apparent influence on daily weight gain (McCartor et al. 1979). As propionate is the primary gluconeogenic precursor for ruminant animals, these results indicate that glucose status affects the rate of reproductive development. A more recent study (Moseley et al. 1982) reported similar findings, although only in heifers that were relatively heavy at weaning and which maintained their growth advantage. Onset of puberty may be limited by age in the faster growing animals and by weight in slower growing animals. In extreme situations, such as induction of hypoglycaemia following administration of insulin (McClure, 1968) or by the hypothalamic glucose receptor antagonist, 2-deoxyglucose (Crump et al. I982), ovarian activity will be inhibited in ruminants apparently by inhibition of gonadotrophin-releasing hormone (GnRH, Table 3). Alternatively, giving monensin to prepubertal heifers results in an increased luteinizing hormone ( $\mathrm{LH}$ ) response to $\mathrm{GnRH}$ or oestradiol (Randel \& Rhodes, 1980a,b).

Table 3. The influence of 2-deoxyglucose $(2 D G)$ on the luteinizing-hormone $(L H)$ response to oestradiol $1_{7} \beta\left(E_{2}\right)$ or $L H$ releasing hormone ( $\left.L H R H\right)$ in sheep (from Crump et al. 1982)

(Mean values with their standard errors)

\begin{tabular}{|c|c|c|c|}
\hline \multirow[b]{2}{*}{ Treatment } & \multicolumn{2}{|c|}{ Peak LH $(\mathrm{ng} / \mathrm{ml})$} & \multirow{2}{*}{$\begin{array}{c}\text { Peak time }(\mathrm{h}) \\
\text { (from } \\
\text { administration of } \\
\text { E2 or I.HRH) }\end{array}$} \\
\hline & Mean & $S E$ & \\
\hline Saline + E2 & 59.9 & I 75 & 125 \\
\hline $2 \mathrm{DG}+\mathrm{E}_{2}$ & $29 \cdot 2$ & $3 \cdot 3$ & $16 \cdot 5$ \\
\hline Saline + I.IIRII & $28 \cdot 7$ & 5.5 & I 2 \\
\hline${ }_{2} \mathrm{DG}+\mathrm{I} \cdot \mathrm{HRH}$ & $29 \cdot 7$ & $6 \cdot 1$ & $1 \cdot 0$ \\
\hline
\end{tabular}


Protein intake. Moderate protein restriction during the rearing period did not influence attainment of puberty in gilts (den Hartog \& van Kempen, r980), although a severe protein restriction will delay the onset of puberty in gilts (Aherne \& Kirkwood, 1985) and rats (Widdowson \& Cowen, r 972; Table 4). The results of Bakke et al. (1975) and Ronnekleiv et al. (1978) suggested that preweaning undernutrition had no effect on the pubertal age of rats, whereas earlier findings (Kennedy, 1957; Widdowson \& McCance, I960; Kennedy \& Mitra, 1963) did. The contrasting results may be explained, in part, by differences in dietary protein content; the earlier workers gave a postweaning diet having $400 \mathrm{~g}$ less protein $/ \mathrm{kg}$ than the latter. Higher postweaning intakes may have alleviated the effects of poor preweaning nutrition.

Amino acid balance of the dietary protein may influence reproductive development. Providing wheat protein as the only protein source has been shown to disrupt oestrous cycles in rats (Evans' \& Bishop, 1922), but the effect was reversed by the addition of lysine to the diet (Pearson, 1937). Age at puberty was lower in pigs fed on protein of animal and plant origin compared with those fed on a protein entirely of plant origin (Fowler \& Robertson, 1954). The mechanism whereby an amino acid imbalance or deficiency delays puberty is not known. A deficiency of amino acid precursors for the synthesis of peptide hormones has been suggested (Glass et al. 1976). Studies with gilts have shown that supplementing the diet with amino acids that are precursors to brain neurotransmitters may facilitate ovulation (Christopherson et al. 1985). Supplementing the diet with tyrosine (a precursor of dopamine and noradrenaline) increased the number of prepubertal gilts ovulating in response to exogenous oestradiol (Table 5). Furthermore, differences werc noted in the interval between oestradiol injection and peak plasma LH levels, and in the pattern of LH release (R. J. Christopherson, unpublished results).

Growth rate and body composition. Rapidly growing animals tend to achieve puberty earlier than animals growing more slowly. This has been demonstrated in rats (Glass et al. 1976), cattle (Short \& Bellows, I 97I), sheep (Dyrmundsson, I98 I)

Table 4. The influence of dietary protein restriction on the age and body-weight at vaginal opening in rats (from Widdowson $\mathscr{E}^{\circ}$ Cowen, 1972)

(Mean values with their standard errors)

\begin{tabular}{|c|c|c|c|c|}
\hline \multirow[b]{3}{*}{ Treatment } & \multicolumn{4}{|c|}{ Vaginal opening } \\
\hline & \multicolumn{2}{|c|}{$\underbrace{A g e(d)}$} & \multicolumn{2}{|c|}{ Wt $(g)$} \\
\hline & Mean & $\mathrm{SE}$ & Mean & $\mathrm{SE}$ \\
\hline $\begin{array}{l}\text { Control ( } 180 \mathrm{~g} \text { protein } / \mathrm{kg} \text { ) } \\
\text { Protein-deficient: }\end{array}$ & $39 \cdot 6$ & $2 \cdot 0$ & $88 \cdot 8$ & 10.4 \\
\hline $\begin{array}{l}90 \mathrm{~g} \mathrm{protein} / \mathrm{kg} \\
60 \mathrm{~g} \mathrm{protein} / \mathrm{kg}\end{array}$ & $\begin{array}{l}56 \cdot 8 \\
75 \cdot 6\end{array}$ & $\begin{array}{r}8 \cdot 0 \\
18 \cdot 0\end{array}$ & $\begin{array}{l}96 \cdot 9 \\
86 \cdot 0\end{array}$ & $\begin{array}{l}16 \cdot 8 \\
22 \cdot 8\end{array}$ \\
\hline
\end{tabular}


Table 5. Effect of tyrosine and tryptophan supplementation on the percentages of prepubertal gilts showing oestrus cycles following injection of $\beta$-oestradiol3-benzoate at 100 d of age (from Christopherson et al. 1985)

$\begin{array}{ccc} & \begin{array}{c}\text { Percentage of gilts showing } \\ \text { oestrus cycles }\end{array} \\ \text { Treatment } & \text { One cycle } & \text { Two cycles } \\ \text { Control } & 50 & 12.5 \\ \text { Tyrosine } & 75 & 12.5 \\ \text { Tryptophan } & 25 & 125\end{array}$

and pigs (Friend, 1976). The relation between growth and reproductive development is unclear. It may simply be the more rapid achievement of a body size or weight which is a prerequisite for the onset of puberty. Sorensen et al. (1969) reported close agreement between skeletal measurements at puberty for cattle on various prepubertal nutritional regimens. A minimum body-weight, while a prerequisite for the onset of puberty, is not in itself sufficient to trigger puberty (Kirkwood \& Aherne, 1985). Beyond this as yet undefined minimum, weight per se is relatively unimportant (Quirke, 1979; Kirkwood \& Aherne, 1985).

An apparent paradox has been noted in one study, in that while slower-growing pigs achieved puberty earlier than faster-growing pigs, within the slower-growing population the fastest growers were youngest at puberty (Price et al. 1981; Fig. I). An explanation for this situation has been suggested by Kirkwood \& Aherne

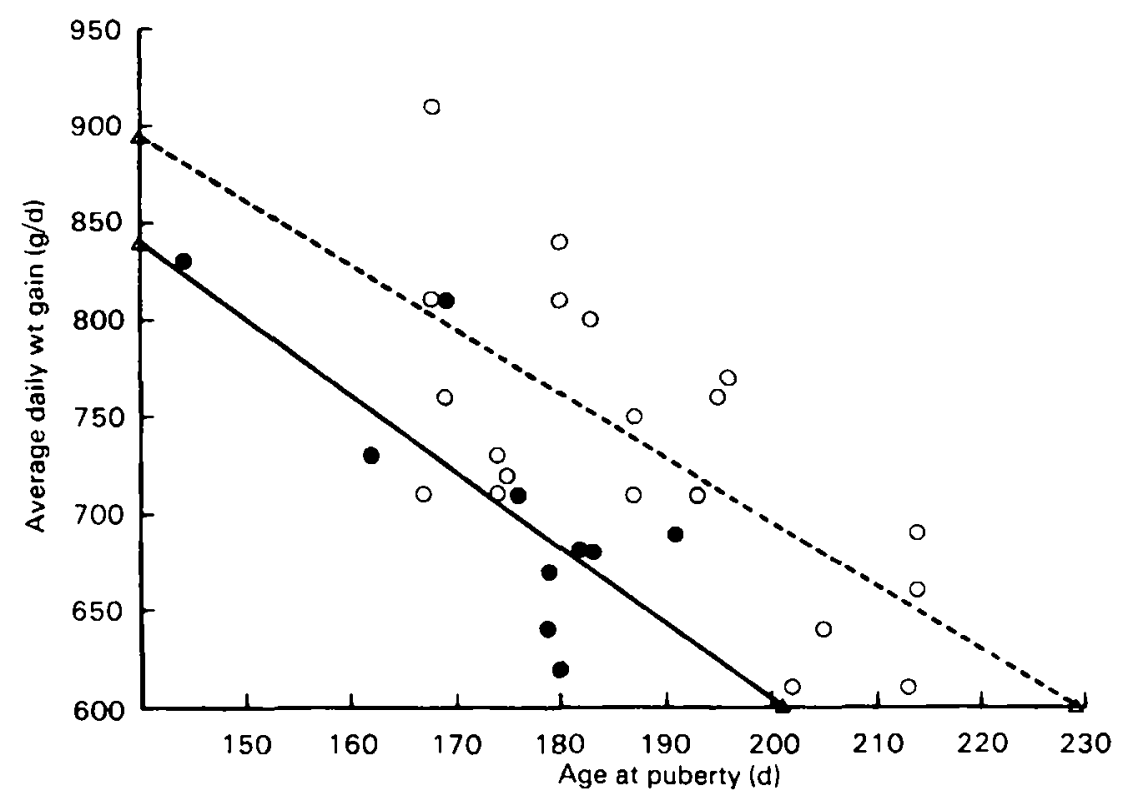

Fig. I. The relation between average daily wcight gain and age at puberty for thirty gilts achieving first oestrus before $109 \mathrm{~kg}$ body-weight. (O, - - ). Gilts ovulating more than once; $(0,--)$ gilts that ovulated once (from Price et al. 1981 ). 
(1985). Briefly, the more slowly growing gilts may have a smaller mature size or greater propensity to fatten, or both. Thus, within this 'fatter' group, the fastest growers achieved a weight threshold earlier and also have some prerequisite 'pubertal' level of body fat. This would imply that growth rate exerts its effect via an influence on body composition. A schematic diagram of tissue growth relative to live weight in cattle is shown in Fig. 2. Fat growth starts out relatively slowly but increases geometrically as an animal enters the fattening phase. The pattern for fat growth is similar for sheep (Fourie et al. 1970), pigs (Richmond \& Berg, 1971) and presumably other species. If puberty is related to a fixed point on the fat growth curve, and if this curve is modified (e.g. nutritionally) then the onset of puberty may also be modified. Indeed, differences in the fat growth curve between early- and late-maturing cattle have been documented (Fig. 2). However, in common with possible age and weight thresholds, a minimum level of body fatness may be required before puberty but its achievement, while necessary, is not sufficient to induce oestrus. The role of body composition in the expression of sexual maturity will be more fully discussed later.

Priorities exist within the animal with respect to the development of individual tissues and organs. If a nutrient restriction is imposed (energy, protein, both or specific amino acids) available nutrients will be directed towards those organs and tissues with a higher priority (e.g. nervous system) at the expense of those with lower priority. The reproductive system has a low priority so under conditions of severe nutrient restriction puberty will be delayed. With less-severe restriction, which still allows the development of the reproductive system, other criteria may

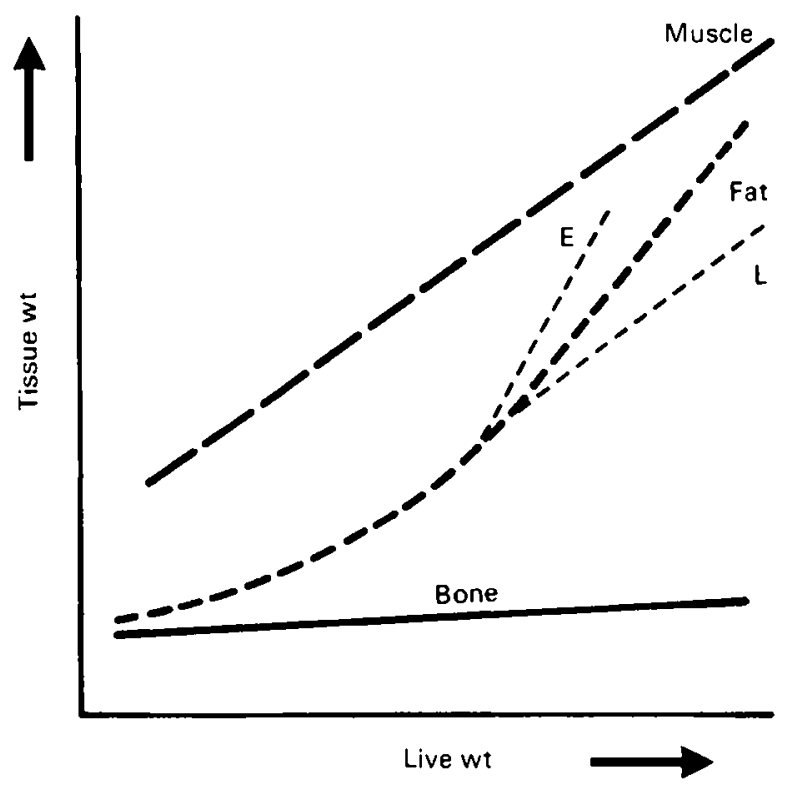

Fig. 2. Tissue growth relative to live weight in cattle and the influence of maturity type (from Berg \& Walters, $19^{8} 3$ ). E, early maturing; $L$, late maturing. 
become operative. It is possible that, as adipose tissue development has a lower priority than lean tissue development, nutrient restriction may delay the acquisition of a minimum level of fatness prerequisite for the onset of puberty until such time as a minimum lean body mass deposition has occurred. Additionally, restriction may delay the achievement of a possible minimum weight requirement necessary for the onset of puberty.

\section{Puberty in humans}

Secular trend towards earlier menarche. Information collected over the last century suggests that the mean age of menarche has declined with the passage of time (Tanner, 1962, 198 ; Fig. 3). More girls enter puberty at an early age (Brown, 1966) but the earliest age of menarche has remained unchanged. The change in age of onset of menstruation has been accompanied by an increase in stature which is clearly apparent in school-age children (Tanner, I 962). Menarche has corresponded with physical size, rather than chronological age (Frisch, 1972) and thus girls are achieving menarche at approximately the same physical size as their mothers, but at an earlier age. As Tanner (1962) pointed out, 9-year-old girls have the same stature and degree of physical development as 10-year-old girls 30 years earlier. There is evidence that the trend towards earlier menarche has halted (Damon, 1974; Tanner, 1981).
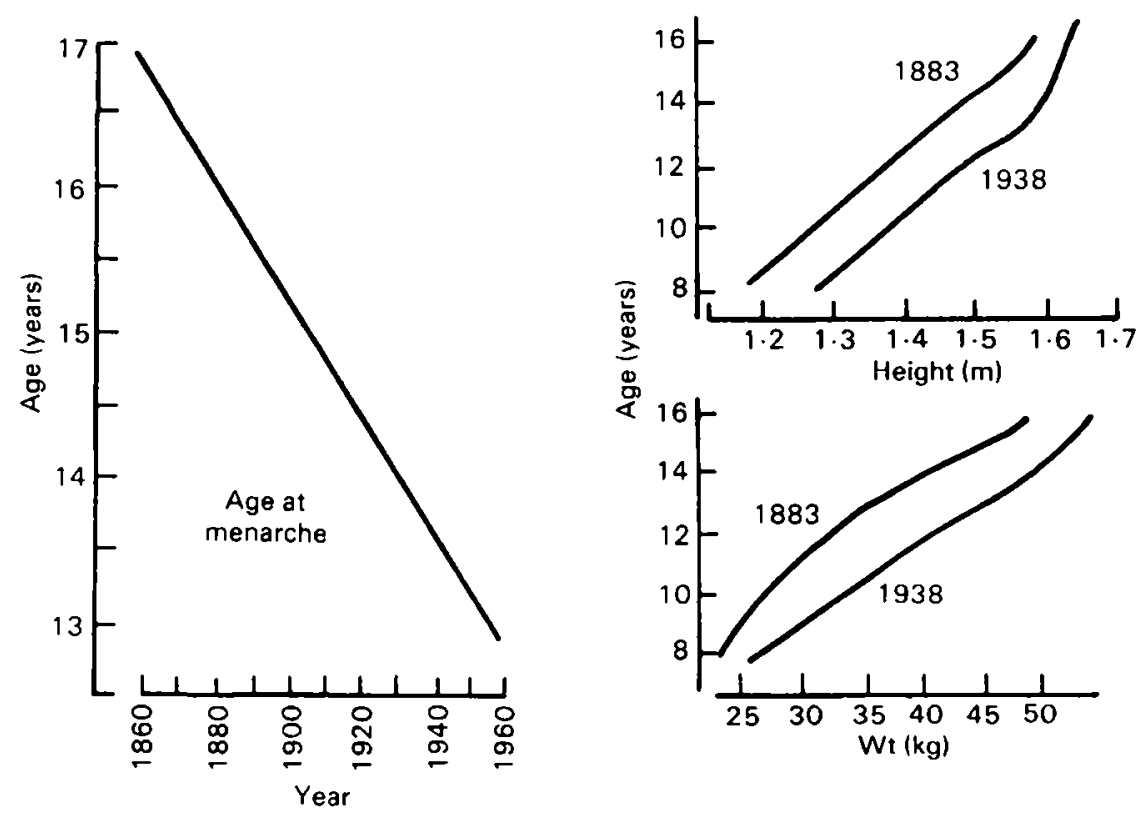

Fig. 3. Age at menarche from 1860 to 1960 (idealized from various sources), and height and weight at various ages from values comparing 1883 with 1938 (from Broman et al. 1942). 
These observations provide circumstantial evidence that nutrition has an effect on the timing of menarche. One might assume that changes in menarcheal age would be less apparent in socio-economic classes where nutrition has traditionally been good. This does not appear to be so, because the age of menarche also seems to have decreased in the privileged classes (Milner-Guilland, 1959). This suggests that factors other than nutrition may be involved. However, in geographic locations where the pattern of nutrition has not changed over many years the age of menarche has not altered (Bojilen $\&$ Bentzon, I 968). For example, in some Inuit, Lapp and East Indian populations, the age of menarche has not changed over at least a generation.

Famine, starvation, socio-economic status and other nutritional factors. Instances of famine and starvation as a result of warfare have provided examples of relatively short-term nutritional stresses. In these circumstances the reproductive consequences (amenorrhoea or infertility) were seen first in women whose previous nutrition was likely to have been marginal before the event (Stein \& Susser, 1975). Weir et al. (1971) studied the reported age of menarche in 37582 women of widely varied ethnic backgrounds in a single geographic area (Los Angeles) and concluded that the economic level with its variables (e.g. level of nutrition), rather than race or geographic location was the primary factor that determined the age of menarche, women from lower socio-economic groups having later menarche.

Baanders-van Halewin \& de Ward (1968) reported that the diets of rural and urban Bantu girls in South Africa were inadequate in protein, carbohydrate and fat compared with European (Dutch) girls throughout childhood and were probably the cause of a difference of over I year in mean age of menarche in the African girls. A difference between diets could also be responsible for a further difference in menarcheal age between urban and rural girls. Others have reported an urban-rural disassociation in menarcheal age in countries where diet has been of borderline adequacy (Wolanski, 1966; Kantero \& Widholm, 1971). Where dietary inadequacy has been observed in the USA, it does have an effect on the age at physical and reproductive maturation. Dreizen et al. (1967) reported a mean age of menarche of 12.4 years where diet was adequate and 14.5 years where there was protein-energy malnutrition. This was accompanied by other signs of delayed skeletal maturation.

In developed countries the most likely cause of dietary inadequacy in the peripubertal period is self-induced. Dieting, weight loss and low body-weight are associated with delayed menarche (Kennedy, 1969).

Reproductive dysfunction is also common in low body-weight women runners, and others who exercise strenuously (Cumming \& Rebar, 1983). Amenorrhoeic runners had a lower percentage body fat than normally menstruating runners who were, in turn, leaner than non-exercising women (Schwartz et al. 198I; Fig. 4). Amenorrhoeic athletes also lose more weight following the onset of their running (Schwartz et al. 1981). However, injuries preventing exercise in amenorrhoeic young ballet dancers precipitated menarche or were accompanied by resumption of menses in the absence of any weight change (Warren, 1980). A significant 'energy 


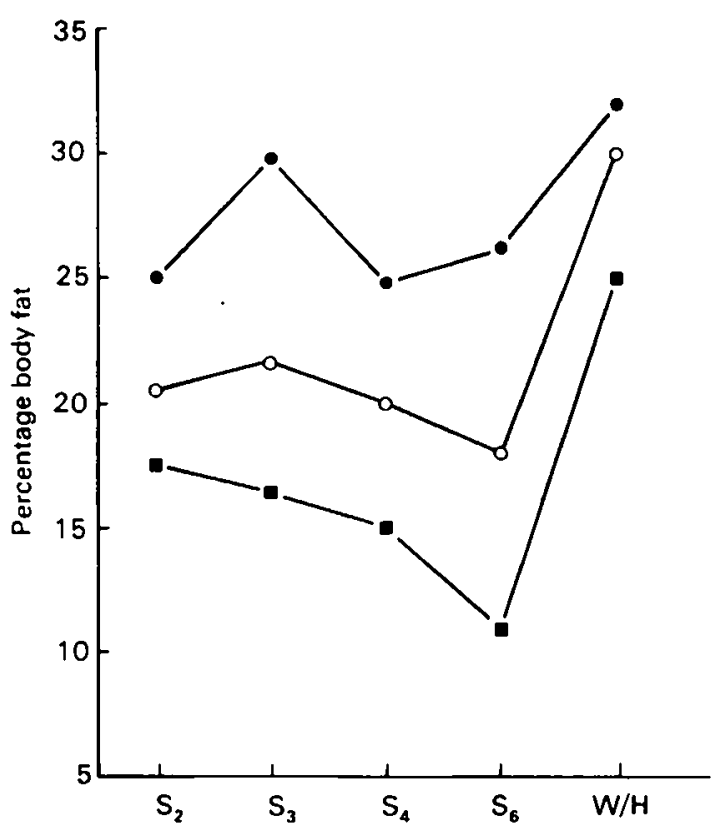

Fig. 4. Estimation of percentage body fat in women calculated by five different methods from skinfold thickness at two $\left(\mathrm{S}_{2}\right)$, three $\left(\mathrm{S}_{3}\right)$, four $\left(\mathrm{S}_{4}\right)$ or $\operatorname{six}\left(\mathrm{S}_{6}\right)$ sites or from weight-for-height $(\mathrm{W} / \mathrm{H})$. $(\bigcirc)$, Normal controls; (O), normally menstruating runners; (匚), amenorrhoeic runners (from Cumming \& Rebar, $\left.198_{4}\right)$.

drain' of exercise alone may delay menarche or result in amenorrhoea. Women beginning training pre-menarcheally had significantly lower fat and protein intakes than in women beginning training post-menarcheally (Frisch et al. r98I), and the incidence of reproductive dysfunction was higher in the former group. Calabrese \& Kirkendall (1983) have shown that ballet dancers consume less energy than the recommended daily allowance but had a satisfactory protein intake, while Schwartz et al. (1981) reported that dietary protein was reduced in amenorrhoeic runners compared with those who had normal menstrual cycles. Thus, evidence suggests that although poor nutrition is not a prerequisite for reproductive dysfunction in women who exercise, it is one factor that makes primary or secondary amenorrhoea much more probable.

Body-zveight and composition. Based on observations linking improved nutrition with a decreased age at menarche, it was suggested that, even in circumstances where nutrition is not in question, the age at which girls have their menarche is more closely related to body-weight than to chronological age (Frisch \& Revelle, 1971a). This led to the hypothesis that a critical body-weight may trigger 
menarche. A later report (Frisch \& Revelle, 1971 $b$ ) suggested that the mean height and weight gains from the initiation of the adolescent growth spurt to maturity at 18 years were similar in early and late maturers and that menarche was related to the achievement of minimum height-for-weight. The mechanism(s) controlling the onset of menarche may involve a change in critical metabolic rate which influenced hypothalamic-pituitary sensitivity to circulating steroids (Frisch \& Revelle, I97I $b$ ).

The hypothesis that a relation exists between height, weight and menarche has undergone further development. Maturation involves a decrease in body water throughout puberty (Fries-Hansen, 1956). Total body water, lean body mass and body fat mass were calculated for each of the three pubertal milestones (growth spurt, peak height velocity and menarche). Using the formula of Mellits \& Cheek (1970), the coefficient of variation for total body water alone and also total body water as a percentage of body-weight, showed less biological variation than body mass. Using this formula, body fat increased more than lean body-weight between initiation of the adolescent growth spurt and menarche. This resulted in a change in lean body-weight:body fat ratio from $5: 1$ to $3: 1$ (Frisch et al. 1973). The increase in body fat roughly corresponds to the energy requirement for pregnancy and 3 months of breast feeding, a coincidence which assumed teleological significance (Frisch, 1984). This again suggests that the achievement of a preset minimum level of adiposity is involved in the final maturation leading to menarche, although whether it is a cause or an effect is yet to be determined.

The finding that late maturers gained fat more slowly than early maturers focused attention on percentage body fat as a 'trigger' controlling the onset of menarche. The findings on which this theory was based are cross-sectional and derived rather than observed. Some studies have supported the theory (cited in Wishik, 1977) but detailed criticisms of the minimal body fat hypothesis have been published. The variability of the subjects in Frisch's ( 1984) study can be seen from her scattergrams. Others have disputed both the repeatability of the original findings (Johnston et al. 1975; Billewicz et al. 1976), the accuracy of the methodology (Reeves, 1979; Cumming \& Rebar, 1984; Fig. 5) and the statistical validity of the conclusions drawn from it (Johnston et al. 1975; Trussel, 1978). The hypothesis that a minimal percentage body fat is a prerequisite for menarche (or first oestrus in other species) remains unproved. However, if such is the case, its achievement, while necessary, will not be in itself sufficient to trigger the event.

\section{Hormones and puberty}

The attainment of puberty in the female is associated with an increased level of biologically potent plasma gonadotrophins (Luckey et al. 1980). This in turn leads to ovarian follicular development and a consequent increase in circulating gonadal steroid hormones. In the prepubertal period oestrogen acts at the level of the hypothalamus to suppress I.H release (negative feedback). At the time of puberty the hypothalamic regulator (the 'gonadostat') loses sensitivity and so allows an 

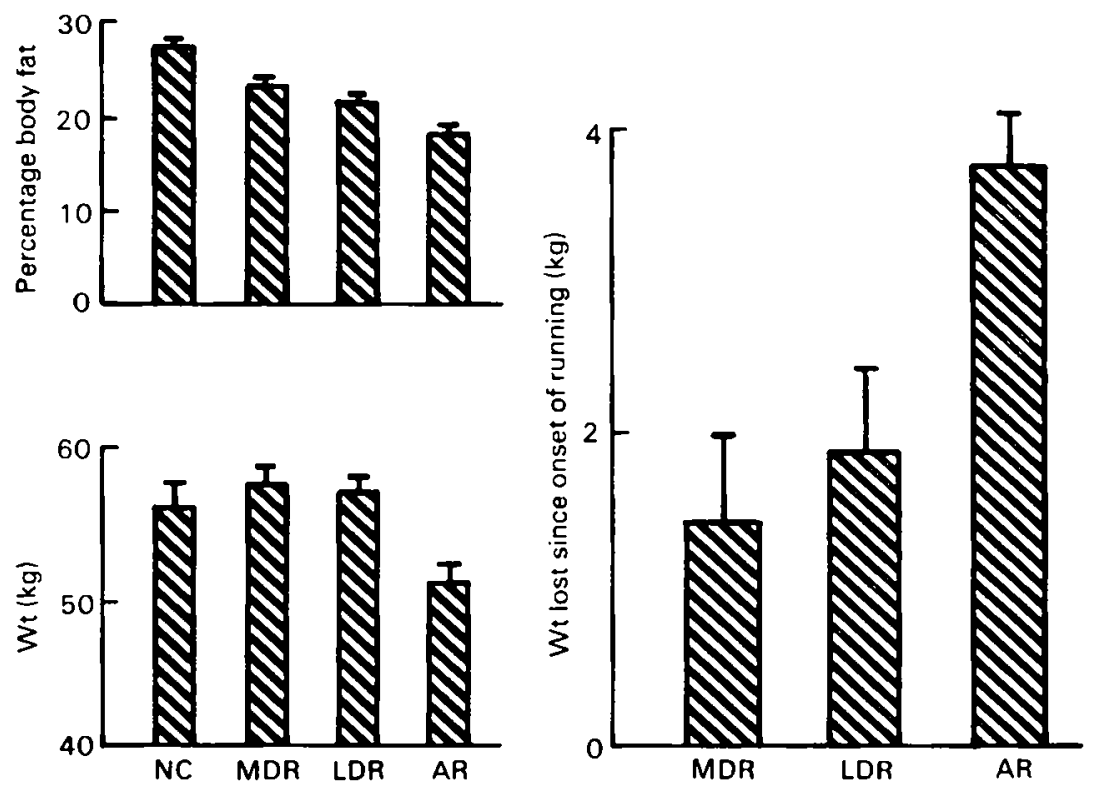

Fig. 5. Percentage body fat, body-weight (kg) and weight lost since beginning running in normally menstruating women running 8-32 (MDR) or $32+$ (LDR) km/week, amenorrhoeic rinners (AR) and normal, control, non-exercising women (NC) (from Cumming \& Belcastro, I982).

increase in $\mathrm{LH}$ release and thus also further oestrogen production. When serum levels of oestrogen achieve relatively high levels, the preoptic area of the hypothalamus is stimulated and causes a large release of LH (positive feedback) resulting in the pubertal ovulation.

Having described the endocrine events preceding puberty (albeit very simply), we will review the evidence for nutritional influences on the development and expression of the previously described processes. For simplicity, the gonadotrophins (e.g. LH) and steroids (e.g. oestrogen) will be dealt with separately and the discussion will involve both human and animal studies.

The gonadotrophins. Plasma gonadotrophins were reported to be significantly lower in children with poor nutrition than in age-matched controls with a more affluent background (Kulin et al. 1984). Chakravarty et al. (1982) found very low levels of serum gonadotrophins in children with either marasmus or kwashiorkor. A reduction in plasma $\mathrm{LH}$ levels has also been noted in ewe lambs raised on restricted nutrition (Quirke \& Gosling, 1979). Furthermore, severe feed restriction has been shown to reduce the LH pulse frequency in ewe lambs (Foster \& Ostler, 1985). The mechanism whereby poor nutrition decreases plasma gonadotrophin is not known. However, it has been shown that the oestrogen negative feedback is more sensitive in underfed animals (Howland \& Ibrahim, 1973; Foster \& Ostler, 1985). This increased sensitivity will in turn limit gonadotrophic stimulation of the ovary and hence delay or prevent the pubertal ovulation. The findings of Ronnekleiv et al. (1978) support this suggestion, as exogenous oestradiol will 
trigger the positive oestrogen feedback and cause ovulation even in severely malnourished females. However, there are few experimental findings related to the effect of poor nutrition on dynamic functioning of the hypothalamic-pituitarygonadal axis in the prepubertal female, although this has been extensively studied in the adult female, particularly in human secondary amenorrhoea associated with simple weight loss and anorexia nervosa.

Poor nutrition in postpubertal women has been associated with low plasma sex steroid and gonadotrophin levels (Vigersky et al. 1976a; Beumont et al. 1976). Decreased pulsatile release and impaired gonadotrophin response to gonadotrophin-releasing hormone have also been reported, with a sequential improvement in both with weight gain during refeeding (Boyar et al. 1974; McArthur et al. 1976; Nillius \& Wide, 1977; Katz et al. 1978). Similar findings have been noted in pigs (Armstrong \& Britt, 1985) and cattle (Imakawa et al. 1984; Rutter \& Randel, 1984; Fig. 6). A correlation has been observed between plasma gonadotrophin levels and percentage ideal body-weight in women (Sherman et al. I975; Beumont et al. 1976; Vigersky et al. 1976a,b). The lack of comparable information in malnourished prepubertal subjects makes comparisons difficult but it seems probable that similar results would be found. The role of bio$v$. immuno-activity in delayed puberty and secondary amenorrhoea associated with malnutrition remains to be further elucidated.

Oestrogen. Although puberty is preceded by follicular development and increased production and release of oestrogen, the absolute plasma level of oestrogen is of limited importance unless it is biologically active. It has been shown that, in developing rats, high circulating levels of total oestradiol- $7_{7} \beta$ are present

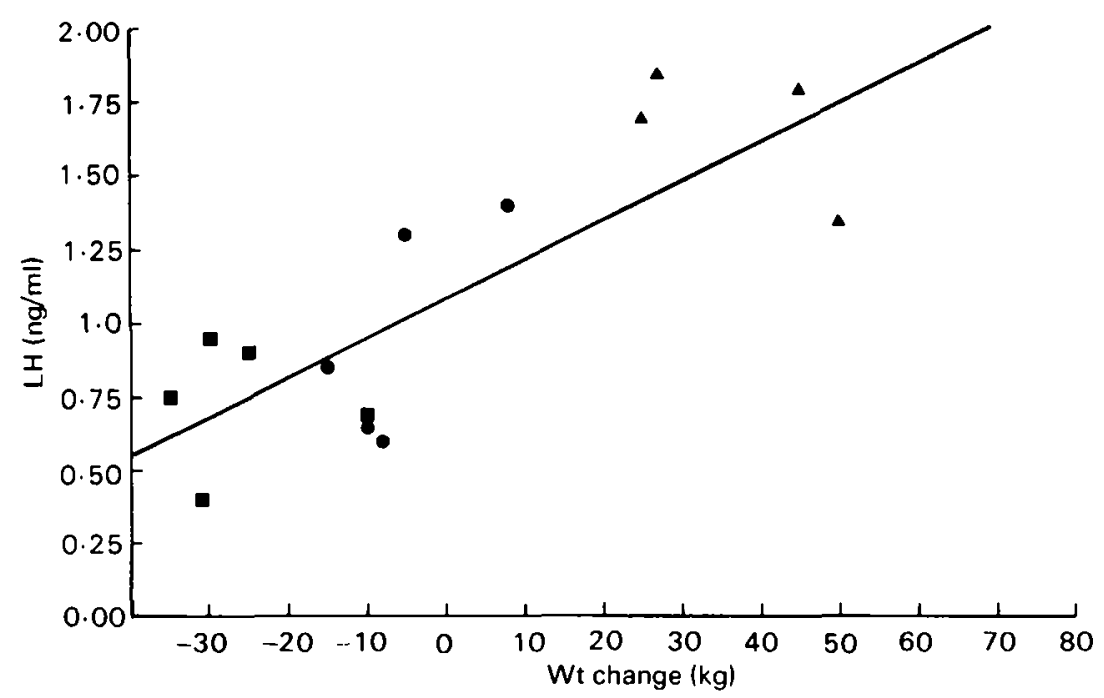

Fig. 6. Linear regression of mcan luteinizing hormone $(\mathrm{LH})$ concentration on weight change in heifers given three levels of energy (from Imakawa et al. 1984): (D), low-energy diet, 28.5 MJ metabolizable energy (ME)/d; (O), maintenance dict, 53.2 MJ ME/d: ( 4 ), high-energy diet, $80 \cdot 4$ $\mathrm{MJ} \mathrm{ME} / \mathrm{d}$. 
from an early age ( $10 \mathrm{~d}$ ), falling to low levels only after $20 \mathrm{~d}$ of age (MacKinnon et al. 1978). However, these high oestradiol levels are not biologically active, as evidenced by high levels of plasma follicle stimulating hormone (FSH), because the hormone is avidly bound to a plasma globulin ( $\alpha$-feto protein). Adult levels of free oestradiol $(4 \%)$ were not apparent until about $30 \mathrm{~d}$ of age, a time near when puberty could be expected to occur in rats (MacKinnon et al. 1978). Undernutrition of rat pups during lactation led to a delay in the 3rd-week drop in plasma FSH and reduced ovarian development (Schenck et al. 1980). It was suggested by Schenck et al. (1980) that the delay in the development of an effective oestrogen negative feedback may be due to a persistent high plasma level of $\alpha$-feto protein. An influence of nutritional status on levels of free and bound oestrogen has also been reported in humans. Serum sex-hormone-binding globulin (SHBG) in plasma is reduced in obese women resulting in an increased percentage of free serum oestradiol (Plymate et al. 1981). Therefore, the changes in the proportion of body fat may influence human reproduction through the intermediate effects of SIIBG. It should, however, be noted that the patients in the Plymate et al. (1981) study do not represent normal physiology.

Level of fatness has also been shown to influence the direction of oestrogen metabolism in women to produce more, or less, biologically active hormones (Fishman et al. 1975). This study, while interesting, involved extremes of body fat content (anorexic, control and obese) and more information is required from less-extreme comparisons. A further mechanism whereby nutrition may modulate the effects of oestrogen is through changes in steroid metabolic clearance rate (MCR). A reduction in oestradiol $\mathrm{MCR}$ has been associated with pubertal development in pigs (Elsaesser et al. 1982) and rhesus monkeys (Macaca mulatta; Hotchkiss, 1983). If poor nutrition results in the maintenance of a high oestradiol MCR, the effectiveness of the oestrogen feedback signal normally resulting in the pubertal ovulation will be limited. Finally, it has been suggested that adipose tissue may be a significant extra-gonadal source of plasma oestrogen by virtue of its ability to aromatize androgens to oestrogens (Siiteri \& MacDonald, 1973). However, it remains to be determined whether fatness is influencing plasma oestrogen levels, or whether plasma oestrogen levels are influencing fatness. It is interesting that plasma steroids can influence voluntary feed intake (Dalvit, 198r) which may eventually result in changes in body composition.

It remains to be established whether the various relations which have been postulated do send metabolic or hormonal messages permitting the final stages of puberty. An alternative is that the body physique and time of reproduction may both be the result of some predetermined developmental plan. Indeed, the changing sex steroids could send metabolic and hormonal messages, e.g. increased growth hormone response to stimuli through puberty with increasing androgens (Wall \& Cumming, 1985). Increased levels of plasma growth hormone advance puberty onset (Sheikholislam \& Stempfel, 1972), possibly by a synergistic action of somatomedin C with FSH on ovarian development (Adashi et al. 1984). 


\section{REFERENCES}

Adashi, E. Y., Resnick, C. E., Svoboda, M. E. \& Van Wyk, J. J. (1984). Endocrinology 116, $2369-2375$.

Aherne, F. X. \& Kirkwood, R. N. (1985). Fournal of Reproduction and Fertility 33, Suppl., $169-183$.

Arije, G. F. \& Wiltbank, J. N. (1971). Journal of Animal Science 33, 401--406.

Armstrong, J. D. \& Britt, J. H. ( ( 985 ). Journal of Reproduction and Fertility 33, Suppl., Abstr.

Asdell, S. A. (1946). Patterns of Mammalian Reproduction. Ithaca, New York: Comstock.

Baanders-van Halewin, E. A. \& de Ward, F. (1968). Human Biology 40, 314-322.

Bakke, J. L., Iawrence, N. L., Bennet, J. \& Robinson, S. (1975). Biology of the Neonate 27 , 259-270.

Beumont, P. J. V., George, G. C. W., Pimstone, B. L. \& Vinik, A. L. (1976). Fournal of Clinical Endocrinology and Metabolism 43, 487-496.

Berg, R. T. \& Walters, L. E. (1983). Fournal of Animal Science 57, Suppl. 2, 133-146.

Billewicz, W. Z., Fellows, H. M. \& Hytten, C. A. (1976). Annals of Human Biology 3, 51-59.

Bojilen, K. \& Bentzon, M. (1968). Human Biology 40, 69-85.

Boyar, R. M., Katz, J., Finkelstein, J. W., Kapen, S., Weiner, H., Weitzman, E. D. \& Hellman, L. (1974). New England Yournal of Medicine 291, 86 I-865.

Broman, B., Dahlberg, G. \& I ichtenstein, A. (1942). Acta Paediatrica 30, I.

Brown, P. E. (1966). British Journal of the Society of Preventative Medicine 20, 9-14.

Calabrese, L. H. \& Kirkendall, D. T. (1983). Clinical Sports 2, 539-547.

Chakravarty, I., Sreedhar, R., Ghosh, K. K. \& Bulusu, S. (1982). Fertility and Sterility 37, $650-654$.

Christopherson, R. J., Evans, M. \& Evans, F. D. (1985). Feeders' Day Report, University of Alberta 64, 45-47.

Crump, A. D., Lomax, M. A. \& Rodway, R. G. (1982). Journal of Physiology 330, 93-94.

Cumming, D. C. \& Belcastro, A. N. (1982). Current Problems in Obstetrics and Gynecology 5 (8), $1-4$ I.

Cumming, D. C. \& Rebar, R. W. (1983). American Fournal of Industrial Medicine 4, I I 3-125.

Cumming, D. C. \& Rebar, R. W. (1984). Fertility and Sterility 41, 739-742.

Dalvit, S. P. (1981). American fournal of Clinical Nutrition 34, 1811-1815.

Damon, A. (1974). Social Biology 21, 8-1 I.

den Hartog, L. A. \& van Kempen, G. J. M. (1980). Netherlands Fournal of Agricultural Science 28, $2 \mathrm{II}-227$.

Dickerson, J. W. T., Gresham, G. A. \& McCance, R. A. (1964). Fournal of Endocrinology 29, II I-I 18.

Dreizen, S., Spirakis, C. N. \& Stone, R. E. ( 1967$)$. Fournal of Pediatrics 70, 256-263.

Dyrmundsson, O. R. (1981). Livestock Production Science 8, 55-65.

Elsaesser, F., Stickney, K. \& Foxcroft, G. (1 982). Acta Endocrinologia 100, 606-6 2.

Etienne, M., Camous, S. \& Cuvillier, A. ( $\left(\mathrm{g}^{8} 8_{3}\right)$. Reproduction, Nutrition et Developpment 23, 309-319.

Evans, H. M. \& Bishop, K. C. (1922). Fournal of Metabolic Research 1, 335-356.

Fishman, J., Boyar, R. M. \& Hellman, L. (1975). Journal of Clinical Endocrinology and Metabolism 41, 489-491.

Foster, D. L. \& Ostler, D. H. (1985). Endocrinology I 16, 375-38 r.

Fourie, P. D., Kirton, A. H. \& Jury, K. E. (1970). New Zealand Yournal of Agricultural Research 13, $753-770$.

Fowler, S. H. \& Robertson, E. L. (1954). Journal of Animal Science 13, 949-954.

Friend, D. W. (1976). Fournal of Animal Science 43, 404-412.

Fries-Hansen, B. J. (1956). Acta Pediatrica ro1, Suppl., I-67.

Frisch, R. E. (1972). Pediatrics 50, 445-450.

Frisch, R. E. (1984). Biological Reviews 59, $161-188$.

Frisch, R. E., Ilegsted, D. M. \& Yoshinaga, K. (1975). Proceedings of the National Academy of Science USA 2, 4172-4176. 
Frisch, R. E., von Gotz-Welbergen, A., McArthur, J. W., Albright, T., Wituschi, J., Bullen, B., Birnholz, J., Reed, R. B. \& Herman, H. (1981). Fournal of the American Medical Association 246, $1559-1563$.

Frisch, R. E. \& Revelle, R. (1971a). Science 169, 397-399.

Frisch, R. E. \& Revelle, R. (19716). Archives of Disease in Childhood 46,695-701.

Frisch, R. E., Revelle, R. \& Cook, S. (1973). Human Biology 45, 469-483.

Glass, A. R., Harrison, R. \& Swerdloff, R. F. (1976). Pediatric Research 10, 95 I-955.

Hotchkiss. J. (1983). Fournal of Clinical Endocrinology and Metabolism 56, 979-984.

Howland, B. E. \& Ibrahim, E. A. (1973). Fournal of Reproduction and Fertility 35, 545-548.

Imakawa, K., Kittok, R. J. \& Kinder, J. E. (1984). Yournal of Animal Science 58, 15 I-I 58.

Johnston, F. E., Roche, H. F., Schell, L. M. \& Wettenhall, N. B. (1975). American fournal of Diseases of Childhood 129, 19-23.

Kantero, R. L. \& Widholm, O. (1971). Acta Obstetrica et Gynecologica Scandinavica 14, Suppl., 7-18.

Katz, J. I., Boyer, R. M., Roffwarg, H., Hellman, L. \& Weiner, H. (1978). Psychosomatic Medicine 40, 549-567.

Kennedy, G. C. (1957). Fournal of Endocrinology 16, 9-1 7.

Kennedy, G. C. (1969). Annals of the New York Academy of Science 157, 1049-1061.

Kennedy, G. C. \& Mitra, J. (1963). Fournal of Physiology 166, 408-4 I8.

Kirkwood, R. N. (1985). Proceedings of VI Western Nutrition Conference, Winnipeg, pp. 88-109.

Kirkwood, R. N. \& Aherne, F. X. (1985). Fournal of Animal Science 60, I 5 1 8-1 529.

Kulin, H. E., Bwibo, N., Mutie, D. \& Santner, S. J. (1984). Journal of Pediatrics ro5, 325-328.

Luckey, A. W., Rich, B. H., Rosenfield, R. C., Fang, V. S. \& Roche-Bender, N. (I980). Fournal of Pediatrics 97, 205-209.

McArthur, J. W., O'Loughlin, K. M., Bertins, I. Z., Johnson, L., Hourihan, J. \& Alonso, C. (1976). Mayo Clinic Proceedings 51, 607-6r6.

McCartor, M. M., Randel, R. D. \& Carroll, L. H. (1979). fournal of Animal Science 48, 488-494.

McClure, T. J. (1968). British Veterinary fournal 124, $126-130$.

Mackinnon, P. C. B., Puig-Duran, E. \& Laynes, R. (1978). Fournal of Reproduction and Fertility 52, 40I-4I2.

Mellits, E. D. \& Cheek, D. B. (1970). Physical Growth and Body Composition, Monographs of Research in Childhood Development 35, $12-26$.

Milner-Guilland, L. (1959). Lancet i, 89r.

Moseley, W. M., Dunn, T. G., Kaltenbach, C. C., Short, R. E. \& Staigmiller, R. B. (Ig82). Journal of A rimal Science 55, 357-362.

Nelson, R. E. \& Robison, O. W. (1976). Journal of Animal Science 43, $7 \mathrm{I}-77$.

Nillius, S. J. \& Wide, L. (1977). In Anorexia Nervosa, pp. 225-24I [R. A. Vigersky, editor]. New York: Raven Press.

Pearson, P. B. (1937). American Fournal of Physiology $118,786-799$.

Plymate, S. R., Fariss, B. L., Bassett, M. L. \& Matej, L. (1981). Fournal of Clinical Endocrinology and Metabolism 52, $1246-1248$.

Price, M. A., Aherne, F. X., Elliot, J. I. \& Lodge, G. A. (I981). Animal Production 33, 159-164.

Quirke, J. F. (1 979). Animal Production 28, 297-307.

Quirke, J. F. \& Gosling, J. P. (1979). Animal Production 28, I-I 2.

Randel, R. D. \& Rhodes, R. C. (1980a). Fournal of Animal Science 51, Suppl. I, 319.

Randel, R. D. \& Rhodes, R. C. ( 19806 ). Fournal of Animal Science 51, 925-931.

Reeves, J. (1979). Science 204, $88 \mathrm{r}$.

Richmond, R. J. \& Berg, R. T. (1971). Canadian fournal of Animal Science 51, 31-39.

Ronnekleiv, O. K., Ojeda, S. K. \& McCann, S. M. (1978). Biology of Reproduction 19, 414-424.

Rutter, L. M. \& Randel, R. D. (1984). Fournal of Animal Science 58, 265-274.

Schenck, P. E., Loss Slob, A., Uilenbroek, Th. J. \& van der Werff Ten Bosch, J. J. (1980). British Fournal of Nutrition 44, $179-182$.

Schwartz, B., Cumming, D. C., Riorden, E., Selyc, M., Yen, S. S. C. \& Rebar, R. W. (198I). American Fournal of Obstetrics and Gynecology 141, 662-670.

Sheikholislam, B. M. \& Stempfel, R. S. (1972). Pediatrics 49, 362-374. 
Sherman, B. M., Halmi, K. A. \& Zamudis, R. (1975). Fournal of Clinical Endocrinology and Metabolism 41, $135^{-1} 4^{2}$.

Short, R. E. \& Bellows, R. A. (1971). Journal of Animal Science 32, 127-1 31.

Siiteri, P. K. \& MacDonald, P. C. (I973). In Handbook of Physiology, Section 7, Endocrinology, vol. 2, pp. 615-629 [S. R. Geiger, E. B. Astwood and R. O. Greep, editors]. Washington DC: American Physiological Society.

Sorensen, A. M., Hansel, H., Hough, W. H., Armstrong, D. T., McEntee, K. \& Bratton, R. W. (1969). Bulletin Cornell University Agricultural Experiment Station no. 936.

Stein, Z. \& Susser, M. (1975). Human Biology 47, I3 I-1 54 .

Tanner, J. M. (1962). Growth and Adolescence, 2nd ed. Philadelphia: Blackwell Scientific.

Tanner, J. M. (198I). Science 214,6r4.

Trussel, J. (1 978). Science 200, I 506-I 509.

Vigersky, R. A., Loriaux, D. L., Andersen, A. E. \& Lipsett, M. B. (1976a). Fournal of Clinical Endocrinology and Metabolism 43, 51 7-535.

Vigersky, R. A., Loriaux, D. L., Andersen, A. E., Mecklenberg, R. S. \& Vaitukaitis, J. (1976b). fournal of Clinical Endocrinology and Metabolism 43, 893-900.

Wall, S. R. \& Cumming, D. C. (1985). Seminars in Reproductive Endocrinology 3, 65-80.

Warren, M. P. (1980). Fournal of Clinical Endocrinology and Metabolism 51 , 1 1 $50-1$ I 57.

Weir, J., Dunn, J. E. \& Jones, E. G. ( (1971). American fournal of Obstetrics and Gynecology I I I, $594-596$.

Widdowson, E. M. \& Cowen, J. (1972). British fournal of Nutrition 27, 85-95.

Widdowson, E. M. \& McCance, R. A. (1960). Proceedings of the Royal Society (London) Scr. $B$ $152,188-206$.

Wishik, S. M. (1977). In Nutritional Impacts on Women Throughout Life with Emphasis on Reproduction, pp. 23-29 [K. S. Moghissi and T. N. Evans, editors]. New York: Harper and Row.

Wolanski, N. (1966). Annals of the New York Academy of Science 134, 826-840. 